\title{
Rice husk as sustainable waste energy for small farmers - A review
}

\author{
I Gede Bawa Susana * and Ida Bagus Alit \\ Department of Mechanical Engineering, Faculty of Engineering, University of Mataram, Jl. Majapahit No. 62 Mataram- \\ Nusa Tenggara Barat 83125, Indonesia.
}

World Journal of Advanced Engineering Technology and Sciences, 2021, 03(02), 001-006

Publication history: Received on 09 August 2021; revised on 18 September 2021; accepted on 20 September 2021

Article DOI: https://doi.org/10.30574/wjaets.2021.3.2.0063

\begin{abstract}
A review of rice husks as an energy source was carried out to provide information on their use in the drying process, especially handling post-harvest for small farmers. This is done because there are still many small farmers who only use the sun to dry their food. Drying is done by dry in the sun and this process still has drawbacks. The weakness of the process of drying in the sun is very dependent on the weather, so when it is cloudy or rainy the drying process will stop. Of course, this causes losses to small farmers, on the other hand, waste is abundant in the form of rice husks. This is related to rice as the farmer's staple crop and rice husk is a by-product of rice production. Based on several studies and libraries, a satisfactory result was obtained regarding rice husks. Rice husk can be used as sustainable alternative energy. Increasing the drying temperature, it can be done through an energy conversion process. This method is carried out by adding a heat exchanger to increase heat transfer from the burning of rice husks to the drying air. This method is also able to shorten the drying time and the dried food becomes hygienic. This is as a result of the drying process of foodstuffs carried out in the drying room, to avoid dirt and dust. Utilization of rice husks and heat exchangers as an alternative in overcoming the problems of conventional agriculture in terms of uncertain weather and climate.
\end{abstract}

Keywords: Rice Husk; Waste Energy; Energy conversion; Small Farmer

\section{Introduction}

Energy is needed by farmers in post-harvest handling in addition to household needs. Energy applications for postharvest related to preserving the resulting product. The easiest preservation is through the drying process. Drying is done directly by dry in the sun or indirectly by using a dryer. Small farmers in Lombok generally take advantage of drying by dry in the sun because it is easy and cheap. This method has the disadvantage that it is very dependent on the weather. When it's raining or cloudy, it causes non-optimal drying. To overcome this, alternative energy can be used, namely through the energy conversion process. Potential alternative energy to be applied to smallholders is biomass.

Biomass is organic material from living bodies in the form of agricultural, plant and animal waste. Some examples of biomass include rice straw, corn cobs, coconut husks, and rice husks. What is being developed at this time is rice husk. Rice husk is a waste from rice production resulting from the rice milling process by $20-30 \%$. Rice husk can cause problems in the environment if its utilization is not optimal. Based on 2019 data, the potential for rice husks on the island of Lombok reached 269,420.20 tons and in West Nusa Tenggara it reaches 533,150.80 tons [1]. Rice husk as sustainable energy has a great opportunity to be applied to small farmers because it is easy to obtain the waste. Several tests carried out on rice husks showed satisfactory results. In [2] it is explained that rice husk can be used as alternative energy for household needs by using a rice husk gas stove for the cooking process. Tests conducted on rectangular fluidized bed combustors showed rice husks produced flame stabilization, low emissions, and combustion efficiency

\footnotetext{
${ }^{*}$ Corresponding author: I Gede Bawa Susana

Department of Mechanical Engineering, Faculty of Engineering, University of Mataram, Jl. Majapahit No. 62 Mataram-Nusa Tenggara Barat 83125, Indonesia.
} 
reached 99.2\% [3]. Rice husk as an energy source can be used directly or indirectly. The direct use is that rice husks are burned directly to produce heat, one of which is using a traditional stove as a substitute for firewood. While indirectly, namely through the energy conversion process. The energy conversion process is carried out by applying a heat exchanger. The heat generated by this method is more optimal and the dried product is not mixed with smoke from burning rice husks.

\section{Scope and Methodology}

The review was conducted for rice husk energy waste. Rice husk is called waste because rice husk is a by-product of rice production. Especially in rural areas where technology is not yet accessible to the people, rice husks are only considered waste. This relates to agricultural business for rural communities more to paddy commodities. The main product is rice with by-products such as straw, bran and rice husk. The use of rice husks by the community is only limited to heating pets such as cows, cooking or burning them directly to clean up the waste. On the other hand, the need for fuel oil and gas for households, especially rural communities, is increasing. This fuel is used for cooking and other needs such as post-harvest drying. Drying using fossil fuels is done as an alternative during the rainy season. When the weather is sunny, drying is done by dry in the sun. Based on [4] dry rice husks can be used as an alternative fuel for household scale, home industry, and drying processes. In addition, rice husks can be used as fuel for traditional stoves or husk stoves for small home industries. Rice husk is a waste that has the potential to be developed as sustainable energy because of its abundant availability. The method in this report uses research results, field observations, and news. Reviews related to renewable energy of rice husks, post-harvest drying, drying methods, energy conversion and dryer applications for small farmers.

\section{Renewable Energy}

Renewable energy is an energy source that comes from natural resources and will not run out because it is formed from sustainable natural processes. Renewable energy that comes from nature can be freely regenerated and renewed infinitely and continuously. Renewable energy can be an alternative energy source because it can be created by utilizing technological developments. Indonesia has considerable potential sources for renewable energy such as hydropower, geothermal, wind, solar, and biomass. Biomass-based energy sources are a potential energy source to replace firewood and coal. This paper, it is specifically discussed related to renewable energy, rice husk biomass. Rice husk is easily obtained by rural communities because most people cultivate agricultural land by planting paddy. Biomass resources have traditionally been used due to their economic potential and volume of agricultural production significant [5]. In addition, in [5] it is also explained that countries with large populations are interested in using renewable energy such as the use of biomass. Biomass can be used as renewable energy by increasing property and logistic factors [6].

\subsection{Rice husk}

Rice husk is a waste that comes from the by-product of rice. Rice as a staple food for Indonesian people, including Lombok, has an impact on rice husks, which are quite abundant. So far, rice husks have only been used for very simple things, such as warming pets or cooking. This is often found in rural communities that work as small farmers. Based on [6] states that rice husk as a biomass waste is very potential for areas with the main food source of rice. With the high potential of rice husks, their utilization in rural communities or small farmers can be increased through the application of appropriate technology. The use of rice husks as fuel can have an impact on maintaining forest sustainability. Logging from the forest will be reduced by using rice husks as fuel to reduce the use of firewood [7]. Rice husk has a net calorific value of $12-16 \mathrm{MJ} / \mathrm{kg}$ [8]; calorific value equivalent to half the calorific value of coal of 11-15.3 MJ/kg [9]; and the average is close to the calorific value of $18 \mathrm{MJ} / \mathrm{kg}$ [10]. The composition of rice husk includes cellulose $50 \%$, lignin (25\%-30\%), bulk density $90-150 \mathrm{~kg} / \mathrm{m}^{3}$, moisture (10\%-15\%), and silica (15\%-20\%) $[11,12]$. The high cellulose composition gives an even and stable combustion effect. Paddy waste in the form of rice husk has the potential to be used as alternative energy. This is to create sustainable renewable energy, especially for small farmers in post-harvest handling in the drying process.

\subsection{Drying method}

The drying process includes direct and indirect drying. Direct drying is done by dry food in the sun or by burning biomass directly. While indirect drying is carried out using a dryer. Indirect drying can be done through an energy conversion process. This process includes converting solar energy into thermal with the help of solar collectors or converting biomass energy into thermal energy with the help of heat exchangers. This review specifically discusses the use of rice husks as the main energy source. 
The direct use of rice husks is still carried out by rural communities such as for the process of burning bricks and pottery. Based on observations in the field and explanations from the community that the rice husks used for the brick-burning process provide uniform heat. In addition, rice husk is easy to obtain and the price is cheap. Several studies related to the use of rice husks as an energy source have been carried out. The use of rice husks as fuel compared to firewood provides a shorter time in the cooking process. This is evidenced from research [13], namely, to boil two-litres of water takes 15 minutes with $1 \mathrm{~kg}$ of rice husks while using firewood takes 21 minutes with $1.2 \mathrm{~kg}$ of firewood. The maximum temperature reached $556.5^{\circ} \mathrm{C}$ when complete combustion occurs after 30 minutes in the test through burning $1 \mathrm{~kg}$ of husk using a stove [14].

Indirect use of rice husk can be done through fluidized-bed and heat exchanger. Tests on rice husks carried out on rectangular fluidized bed combustors showed high combustion efficiency reaching 99.2\%, flame stabilization, and low emissions [15]. The downdraft furnace was developed to overcome the uneven temperature in the use of rice husks [16]. The utilization of rice husks for the drying process through energy conversion is carried out with heat exchangers and furnaces. The application of a heat exchanger has an impact on the drying of foodstuffs that are not polluted by the smoke of burning rice husks. The drying process utilizes air heated by the process of burning rice husks in the furnace. So only hot air enters the drying chamber while the smoke from burning rice husks flows to a different place. The energy conversion process can be used as a solution in the drying process to keep the product clean and hygienic.

\subsection{Energy conversion}

Energy conversion can be used to replace the direct combustion of biomass including rice husks. Direct burning of biomass is an easy and inexpensive way. Direct combustion is one of the main characteristics of biomass which makes it suitable as an energy source for converting plant waste into electricity [17] or direct combustion of biomass in boilers to generate heat at a residential level [18]. However, direct combustion has an impact on food, the environment as well as facilities and equipment. As an alternative, it can be used through the process of converting biomass into thermal. Energy conversion is carried out specifically for application to small farmers by utilizing furnaces and heat exchangers. This method has a significant impact on the increase in temperature and drying time of foodstuffs. In addition, in terms of feasibility, it gives satisfactory results. As in the research results [19, 20] which are presented in Figures 1 and 2.

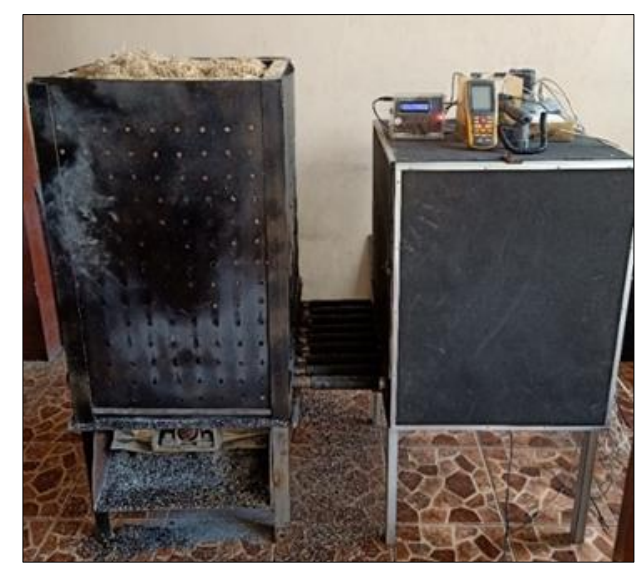

Figure 1 Model of rice husk energy conversion into thermal [19]

The drying temperature through the conversion process of rice husks into thermal reaches $37,09-82,47^{\circ} \mathrm{C}[19]$. When compared with sun drying, it is only able to produce a temperature of $25,80-29,27^{\circ} \mathrm{C}$. The higher temperature generated by the energy conversion process results in a shorter drying time. This is in line with [21] that the longer operating time in the drying process is caused by the lower temperature. The use of energy conversion methods in addition to having an impact on drying time also has an impact on the initial costs that must be incurred by the community using the dryer. But the initial cost is still at an affordable level because it will be covered by more production. This is based on research [19] that conducted a feasibility study on the use of dryers based on energy conversion. From the research, it was found that the payback period for investment costs was 3.3336 months. Research [19] was conducted by testing the dryer to dry jackfruit dodol. The utilization of rice husks in the process of converting biomass into thermal can provide significant results in increasing the added value of paddy waste. This is in line with [22] which states that biomass can be recycled so that it can be used as a reliable energy source. The use of rice husks can reduce agricultural waste because rice is a staple food in Indonesia, including Lombok. The rice husk biomass energy conversion method is suitable for postharvest drying, especially for small farmers because it is easy to operate and affordable. 


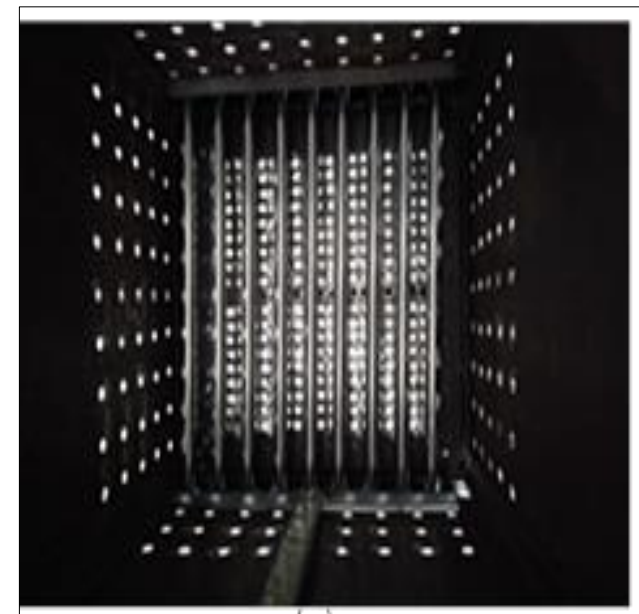

(a)

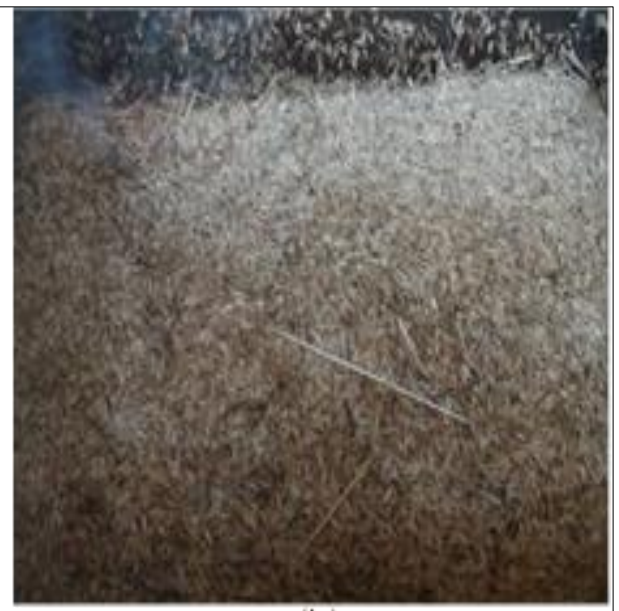

(b)

Figure 2 a) Heat exchanger in the furnace and b) rice husk [20]

\subsection{Dryer application for post-harvest smallholders}

Dryer application based on the method of converting rice husk energy into thermal is very necessary for the postharvest handling of small farmers. Post-harvest handling is an important step to maintain the material quality during storage [23]. The quality of post-harvest products must be maintained to maintain the income of small farmers. This is very necessary because small farmers are very dependent on these agricultural products to meet their daily needs. One of the causes of post-harvest losses in the agricultural sector in most developing countries is poor drying facilities [24]. Utilization of rice husks and the application of heat exchangers to overcome conventional agricultural problems as an alternative to dependence on weather and climate that is less consistent. The addition of a heat exchanger in the rice husk combustion furnace can increase heat transfer to the air-fluid used for the drying process in the drying chamber $[25,26]$. The use of the drying chamber has an impact on the product being dried to be hygienic. In addition, during the drying process, it does not require constant attention as is done during dry in the sun. When compared to dry in the sun, that using a rice husk dryer to dry food requires little attention as rain or animal disturbance [27]. As presented in Figure 3 is the result of research on the application of a dryer using a heat exchanger with rice husk energy sources.

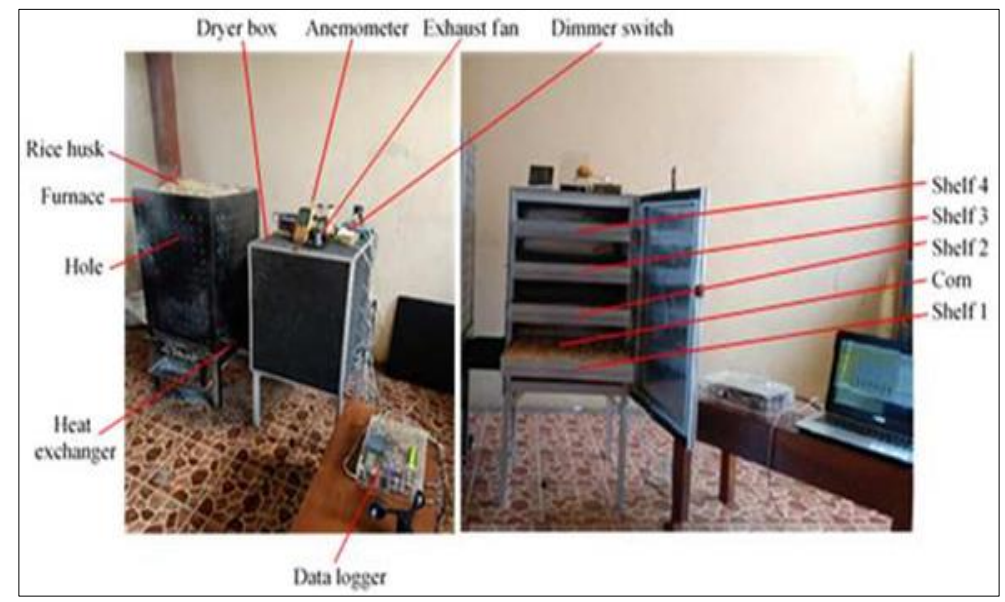

Figure 3 Dryer application in the corn drying process [28]

The test results as shown in Figure 3 produce the average drying temperature on the use of copper, black steel, and stainless-steel pipe types, respectively $67^{\circ} \mathrm{C}, 61.19^{\circ} \mathrm{C}$, and $56.62^{\circ} \mathrm{C}$ [28]. The method as shown in Figure 3 can be used as an alternative in the process of drying food on the scale of small farmers to replace the traditional method which is done by dry in the sun. Poor quality and no strong added value as a result of traditional sun drying because this model drying produces a hard and dusty product [29]. 


\section{Conclusion}

Based on a review conducted on several studies and libraries, it can be concluded that rice husk is suitable for use as sustainable energy for small farmers. Rice husk as an energy source can be used directly or indirectly. Indirect utilization is carried out by the energy conversion method using the help of a heat exchanger. This method can increase the drying temperature and cleanliness of the food to be dried. Utilization of rice husks and heat exchangers as an alternative in overcoming the problems of conventional agriculture in terms of uncertain weather and climate.

\section{Compliance with ethical standards}

\section{Acknowledgments}

The author also wishes to thank the Department of Mechanical Engineering, University of Mataram for facilitating the implementation of this research.

\section{Disclosure of conflict of interest}

The authors declare no conflict of interest.

\section{References}

[1] RUED Provinsi Nusa Tenggara Barat. Potensi Limbah Perkebunan untuk Biomassa. Peraturan Daerah Provinsi Nusa Tenggara Barat. 2019.

[2] Pujotomo I. Potensi pemanfaatan biomassa sekam padi untuk pembangkit listrik melalui teknologi gasifikasi. Jurnal Energi \& Kelistrikan. 2017; 9(2): 126-135.

[3] Chokphoemphun S, Eiamsa-ard S, Promvonge P. Rice husk combustion characteristics in a rectangular fluidizedbed combustor with triple pairs of chevron-shaped discrete ribbed walls. Case Studies in Thermal Engineering. 2019; 14: 1-7.

[4] Litbang Pertanian. Sekam Padi untuk Bangunan dan Bahan Bakar. 2021.

[5] Perea-Moreno MA, Samerón-Manzano E, Perea-Moreno AJ. Biomassas renewable energy: worldwide research trends. Sustainability. 2019; 11(3): 1-19.

[6] Mofijur M, Mahlia TMI, Logeswaran J, Anwar M, Silitonga AS, Ashrafur Rahman SM, Shamsuddin AH. Potential of rice industry biomass as a renewable energy source. Energies. 2019; 12(21): 1-21.

[7] Ahiduzzaman M, Sadrul Islam AKM. Assessment of rice husk briquette fuel use as an alternative source of woodfuel. International Journal of Renewable Energy Research. 2016; 6(4): 1601-1611.

[8] International Finance Corporation. Converting Biomass to Energy: A Guide for Developers and Investors. Pennsylvania Avenue, N.W. Washington, D.C. 2017.

[9] Smith J. Combined Heat and Power from Rice Husks. GMB Energy Central, England, London. 2007.

[10] Awulu JO, Omale PA, Ameh JA. Comparative analysis of calorific values of selected agricultural wastes. Nigerian Journal of Technology (NIJOTECH). 2018; 37(4): 1141-1146.

[11] Singh B. Rice husk ash. Waste and Supplementary Cementitious Materials in Concrete. 2018; 417-460.

[12] Burhenne L, Messmer J, Aicher T, Laborie MP. The effect of the biomass components lignin, cellulose and hemicellulose on TGA and fixed bed pyrolysis. Journal of Analytical and Applied Pyrolysis. 2013; 101: 177-184.

[13] Yahaya DB, Ibrahim TG. Development of rice husk briquettes for use as fuel. Research Journal in Engineering and Applied Sciences. 2012; 1(2): 130-133.

[14] Tangka JK, Ngah JK, Tidze VC, Sako ET. A rice husk fired biomass stove for cooking, water and space heating. International Journal of Trend in Research and Development. 2018; 5(6): 83-89.

[15] Chokphoemphun S, Eiamsa-ard S, Promvonge P. Rice husk combustion characteristics in a rectangular fluidizedbed combustor with triple pairs of chevron-shaped discrete ribbed walls. Case Studies in Thermal Engineering. 2019; 14: 1-7. 
[16] Hung NV, Quilloy R, Gummert M. Improving energy efficiency and developing an air-cooled grate for the downdraft rice husk furnace. Renewable Energy. 2018; 115: 969-977.

[17] Manzano AF. Gasification of greenhouse residues for obtaining electrical energy in the south of Spain: localization by GIS. Interciencia. 2007; 32: 131-136.

[18] Perea-Moreno MA, Manzano-Agugliaro F, Perea-Moreno AJ. Sustainable energy based on sun flower seed husk boiler for residential buildings. Sustainability. 2018; 10: 3407.

[19] Alit IB, Susana IGB. Feasibility analysis of dryer with rice husk energy for drying jackfruit Dodol in Lombok. Global Journal of Engineering and Technology Advances. 2021; 06(03): 075-080.

[20] Alit IB, Susana IGB, Mara IM. Utilization of rice husk biomass in the conventional corn dryer based on the heat exchanger pipes diameter. Case Studies in Thermal Engineering. 2020; 22: 100764.

[21] Bevington PR, Robinson DK. Data Reduction and Error Analysis for the Physical Science. Third ed. McGraw-Hill Companies. 2003.

[22] Logeswaran J, Shamsuddin AH, Silitonga AS, Mahlia TMI. Prospect of using rice straw for power generation: a review. Environmental Science and Pollution Research. 2020; 27: 25956-25969.

[23] Buchori L, Djaeni M, Kurniasari L. Upaya peningkatan mutu dan efisiensi proses pengeringan jagung dengan mixed-adsorption dryer. Reaktor. 2013; 14(3): 193-198.

[24] Nguimdo LA, Noumegnie VAK. Design and implementation of an automatic indirect hybrid solar dryer for households and small industries. International Journal of Renewable Energy Research. 2020; 10(3): 1415-1425.

[25] Susana IGB, Mara IM, Okariawan IDK, Alit IB, Aryadi IGAKCAW. Ash hole variation in rice husk biomass furnace with parallel flow heat exchanger to drying box temperature. ARPN Journal of Engineering and Applied Sciences. 2019; 14(2): 583-586.

[26] Alit IB, Susana IGB. Pengaruh kecepatan udara pada alat pengering jagung dengan mekanisme penukar kalor. Rekayasa Mesin. 2020; 11(1): 77-84.

[27] Delgado-Plaza E, Quilambaqui M, Peralta-Jaramillo J, Apolo H, Velázquez-Martí B. Estimation of the energy consumption of the rice and corn drying process in the equatorial zone. Applied Sciences. 2020; 10(21): 1-21.

[28] Susana IGB, Alit IB. The utilization of rice husk with furnace modification based on the heat exchanger pipe type for sustainable energy of traditional drying. International Journal of Mechanical and Production Engineering Research and Development. 2020; 10(4): 285-294.

[29] Manaa S, Younsi M, Moummi N. Study of methods for drying dates; review the traditional drying methods in the region of Touat Wilaya of Adrar-Algeria. Energy Procedia. 2013; 36: 521-524. 